\title{
Livelihood Security and Sustainability of Ecotourism Destinations in Kerala\#
}

\author{
Bijith George Abraham* \\ Associate Professor and In-charge - Research and International Affairs, SCMS Cochin School of Business, \\ Prathap Nagar, Muttom, Alwaye, Cochin - 683106, Kerala, India
}

\begin{abstract}
Ecotourism is one emerging subsector in tourism, which has immense potential for Sustainable Development. This development of nature-based tourism in Kerala and the associated tourist demand for the destinations is invariably providing livelihood opportunities and wellbeing of the local communities. The paper unveils livelihood security of the community members and sustainable ecotourism development of the destination. Altogether, 600 samples have been collected from three zones based on active community participation in ecotourism programmes. The data was further analysed using Chi-Square, ANOVA, Correspondence Analysis, and Factor analysis. In addition to this, the Standard of Living Index (SLI) was constructed to understand the wellbeing of the community and Income Poverty Dynamics were estimated to highlight income advancement of the community. The result obtained from the study shows a clear-cut picture of community members in terms of their livelihood pattern and how it helped the community members to overcome the burden of poverty visa-vis sustainable development of the destination. As a result, the marginalised sections inhibited in the forest areas have benefitted immensely from the nature-based ecotourism programmes. The community perception indicates that ecotourism has brought environment and economics benefits, participation of local communities and preservation of local culture.
\end{abstract}

Keywords: Community Participation, Ecotourism, Livelihood Security, Poverty Alleviation, Sustainable Development

\section{Introduction}

Tourism sector of Kerala has remarkably grown in the past few years. It has emerged as one of the major contributors to the state GDP with total revenue of Rs. 33,383.68 Crores and Rs. 8,392.11 Crores of Foreign Exchange Earnings (FEEs) (Kerala Tourism Statistics, 2018). The Tourist Arrivals in Kerala is accounted to be 10.92 lakh foreign tourists and 1.47 crores domestic tourists for the year 2017. The initiative of the Kerala tourism focuses on sustainable and eco-friendly development of the tourism sector. With the accelerated investment in the tourism sector, it is likely that the sector would provide employment opportunities for over 10,000 people every year as presented in the
"Citizens Charter of Kerala Tourism". Kerala has been fortunately endowed with immense comparative natural attractions: backwaters, beaches, forests, hillstations, health tourism etc. all preserved in its pristine form. Further investment can be brought if it facilitates sustainable tourism options.

The sustainability concept in the context of tourism and recreation is often associated with discussions of "ecotourism" and "nature-based tourism" (McCool, 1995). Ecotourism is one such emerging subsector in tourism sector for which Kerala has immense potential. The state has the comparative advantage of unspoiled natural endowments and biodiversity surrounded by 17 wildlife sanctuaries and 5 national parks. These

*Email: bijith@scmsgroup.org

\#This research was originally presented in $4^{\text {th }}$ International Conference on "Economic Growth and Sustainable Development: Emerging Trends", organized by SDMIMD on November 23-24, 2018. 
natural acquisitions are guarded in accordance with the local community members for conservation and tourist management. The participation of the local community to the ecotourism programmes ensures environmental conservation and empowers the local people to benefit from the economic opportunities emerging from the nature-based tourism options (TCS evaluation report, 2002).

The community participation in ecotourism has emerged as a tool for biodiversity conservation based on "biodiversity must pay for itself by generating economic benefits, particularly for local people" (Agnes, 2004). While local communities take part in ecotourism activities, it ensures "sustainability in tourism, reduction in poverty, encourage social equity, improve standards of living, increasing local community participation" (Fredline et al. 2006). Hence, it will be beneficial to understand the dynamics of ecotourism as a sustainable development option for the marginalised communities in the state.

The Western Ghats region of Kerala houses majority of the ecotourism destinations, inhabited by the weaker sections of the society "who still lag in the path of development process'. The active participation of these local community members in ecotourism is a workable option to address the livelihood issues of the locales and conservation of the nature. Hence, this paper contributes with more empirical insights to the existing knowledge and highlights the dynamics associated with ecotourism in generating livelihood option, support for conservation, poverty alleviation, and sustainable development of the destination. The aim of this research is to examine the role of community participation in ecotourism in providing livelihood option and its impact on the sustainable development of the destinations.

\section{Theoretical Framework}

The concept of sustainable development is crucial in tourism because "the benefits from tourism resources should be shared between host communities for maintaining the cultural and environmental integrity of the host communities and enhancing the protection of ecologically sensitive areas and natural heritages" (Sharpley, 2010). It gives emphasis to the involvement of local communities, sustainability, and environmental protection. Hence, local community participation into ecotourism brings the socially backward communities to the mainstream through livelihood option, poverty alleviation, conservation of environment thereby facilitates sustainable ecotourism development (Neto, 2003) and also attracts revenues from exports (UNEP, 2013).

The rural local communities comprise of the marginalised sections who earn too little compared with the general public. Thus, ecotourism programme is a workable option in providing the income and employment options to the marginalized people of the society who are dwelling in difficult terrains (Rajasenan and Bijith, 2012). The participation of locals is considered as the best practice to extract positive benefits from tourism (Kepe, 2004). The programmes conducted by local people responsible for the surveillance of the vulnerable parts of the reserve, i.e. involving in the conservation of the forests and valuable revenue generation for community welfare.

The important role of the community is to conserve the nature and educate the visitors. The economic benefit of these activities should be mounted to the local population to ensure sustainability of resources (Thampi, 2005). The participation in ecotourism creates employment, improves standard of living (Bijith and Rajasenan, 2016); it acts as a catalyst for economic development in rural areas (Aref and Gill, 2009) and will open up opportunity for development (NAEB, 2008).

The community participation in ecotourism creates income and employment opportunity to the local communities adhering to the concept of sustainable development, and ecological balance of the destinations (Figure 1). The effectiveness of the ecotourism programme is ascertained through the principles and the guidelines specified by the authorities for Environmental Management. Consecutively, it results in better visitor management, and reduces the negative 


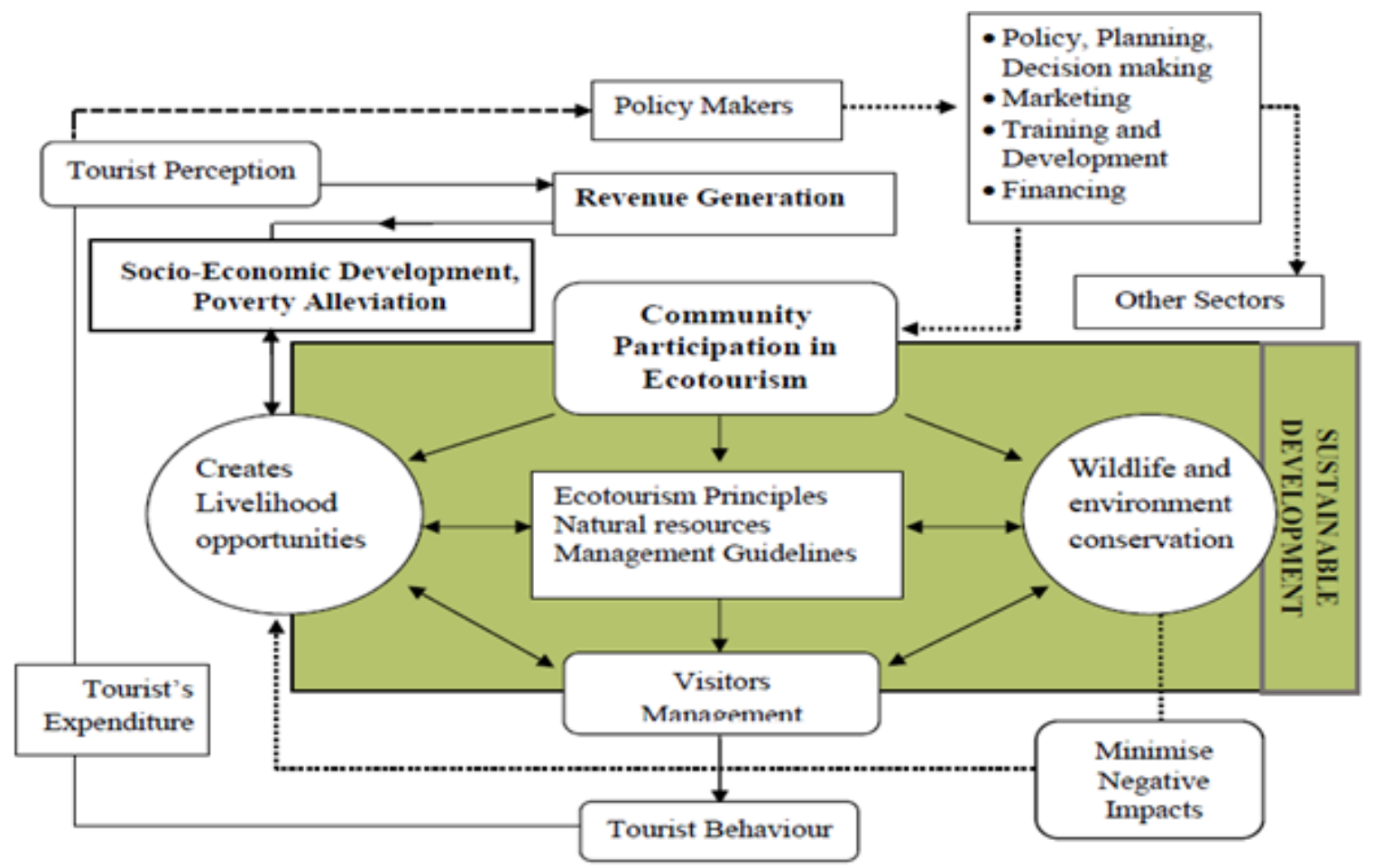

Figure 1. Community based ecotourism management and sustainable development.

Source: Own Formulation

externalities in the destinations. This process assists the policymakers to improvise action plans for effective tourism management, and invariably facilitate a positive impact on allied sectors like hospitality, transportation, infrastructure, small-scale industries etc.

\section{Data and Methodology}

The study is a kind of exploratory-cum-empirical research. Altogether 600 samples from the local community members of three zones (South, Central, and North); 175 from South zone, 250 respondents from Central zone and 175 from North zone were collected for the study. The research was on the regions where there is active participation of the local community in the ecotourism projects located in different parts of Kerala. Both primary and secondary data are used in the study. Communities coming under the Forest Development Agency (FDA) i.e. Eco-Development Communities (EDC) and Vana Samrakshana Samathies (VSS) are the main target groups for the sample survey. The Standard of Living Index (SLI) framework was constructed to understand the wellbeing of the community and Income Poverty dynamics were estimated to highlight income advancement of the community. Employment and livelihood aspect of the ecotourism communities has been analyzed using Chi-Square, ANOVA and Correspondence Analysis. In addition to that, community perceptions were analysed using Factor analysis.

\section{Results and Discussions}

The paper is divided in two sections. The first section comprises of the livelihood and wellbeing of the community members. The second section includes the perception of the community members on ecotourism programmes.

\subsection{Section 1}

\subsubsection{Employment and Livelihood Status}

The livelihood and employment option of the people in the natural settings are seasonal in nature and 
highly dependent on the resources available to them. Ecotourism is a practicable opportunity for these forest dwellers in providing sustainable livelihood option. About ninety percent of the community members work in ecotourism throughout the year other than their alternative livelihood option of collecting forest produce, agriculture and non-agriculture labour, employment guarantee schemes, local vendors/shops etc. In these ecotourism destinations, majority of the respondents are engaged as trekking guides followed by forest watchers, destination cleaners, eco-shops, office jobs including ticket collector, peon, clerical jobs, drivers and others (Figure 2a). Moreover, they are assigned with 15 to 25 days per month as days of employment (Figure 2b). Comparing the three zones, it is evident that there exists difference in terms of the employment option and zones, where Central zone poses more employment above 25 days and North zone have more respondents falling below 14 days.

\subsubsection{Income from Ecotourism}

The survival of these community members in the forest setting were miserable before joining the ecotourism programme. Earlier, they had to depend purely on forest related livelihood option with instable income. However, this situation has totally changed, rather than working as 'poachers and destroyers' of forest,

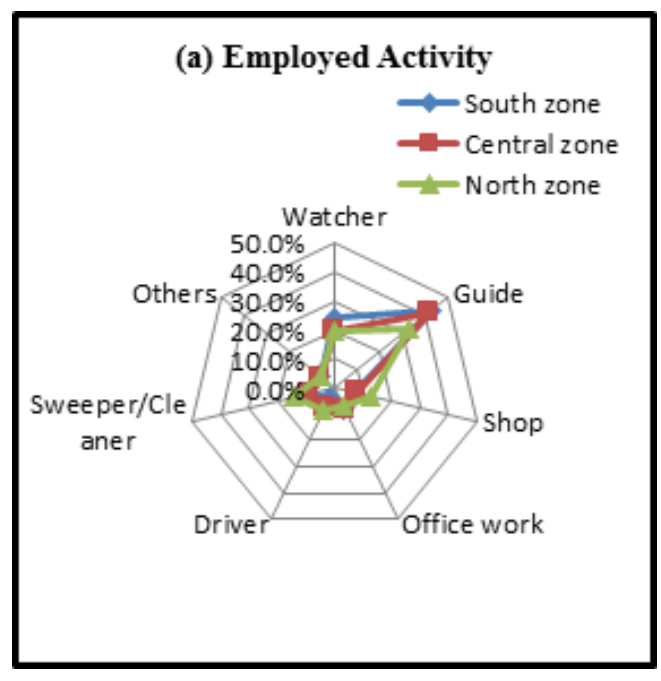

Figure 2. Activity and days of employment.

Source: Survey Data they are now assisting the authorities in conservation as watchers of the forest. Most of the community members are now earning more than what they used to get before working in ecotourism. The error bar plot of income shows variability of data with respect to income (Figure 3) of three zones. The average household income is comparatively high in the Central zone with Rs. 4013/- where as in the South zone the average income is Rs. 3819/- and in the North zone the average income is $3588 /-$ which is low.

Further to check the means income difference, ANOVA is used. Table 1 exhibits that there is a significant difference between the average monthly income and zones, where the F-value is 12.86 and the corresponding $\mathrm{p}$-value is given as $<0.000$.

To understand the mean group differences, the Post Hoc Duncan test is used (Table 2). The mean income is 3588.23 for north zone, 3818.91 for south zone and

Table 1. ANOVA-average monthly income

\begin{tabular}{|l|c|c|c|c|c|}
\hline & Sum of Squares & df & Mean Square & $\mathrm{F}$ & Sig. \\
\hline Between Groups & 18621160.487 & 2 & 9310580.243 & 12.860 & .000 \\
\hline Within Groups & 432217339.471 & 597 & 723982.143 & & \\
\hline Total & 450838499.958 & 599 & & & \\
\hline
\end{tabular}

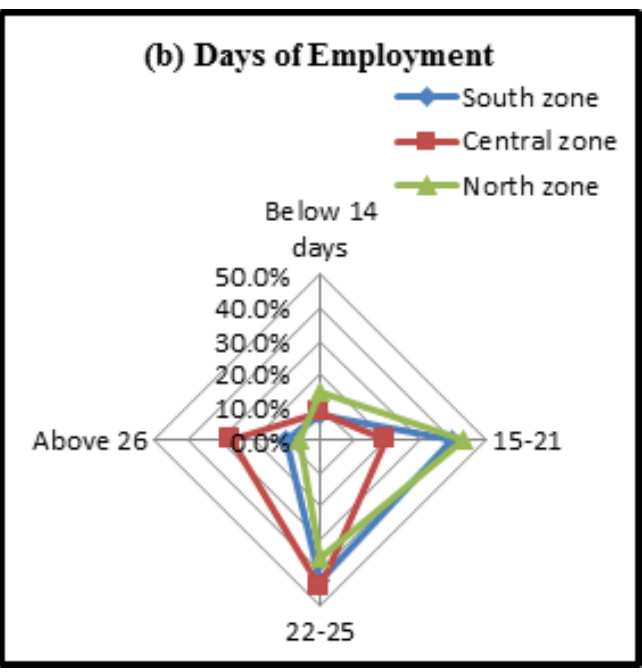




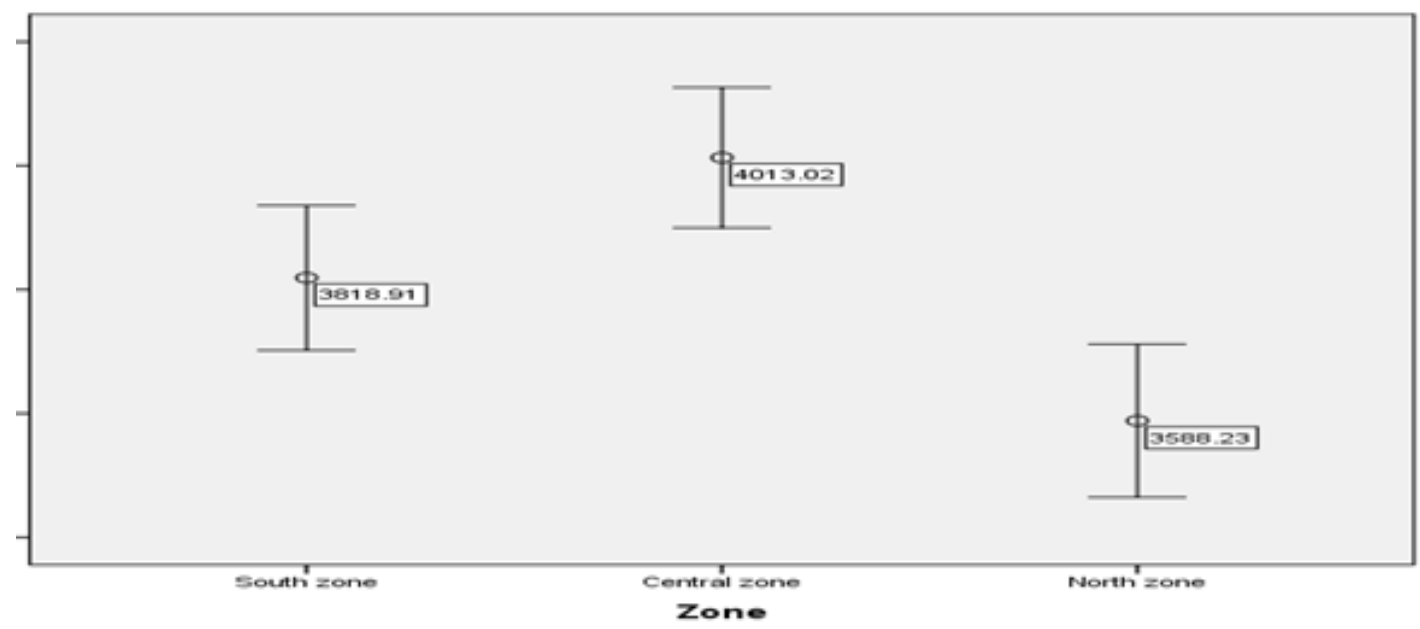

Figure 3. Error bar household income and PCI.

Table 2. Post hoc test-average monthly income

\begin{tabular}{|ll|c|c|c|c|}
\hline Tests & Zone & N & \multicolumn{3}{|c|}{ Subset for alpha $=0.05$} \\
\cline { 4 - 6 } & & & 1 & 2 & 3 \\
\multirow{2}{*}{ Duncan $^{\mathrm{a}, \mathrm{b}}$} & $\begin{array}{l}\text { North zone } \\
\text { South zone }\end{array}$ & 175 & 3588.2286 & & \\
& $\begin{array}{l}\text { Central zone } \\
\text { Sig. }\end{array}$ & 250 & & 3818.9143 & \\
& & & 1.000 & 1.000 & 1.000 \\
\hline
\end{tabular}

4013.02 for central zone respectively. As a result, the Duncan test indicates that the mean incomes of the zones are different from each other, as it does not belong to a homogeneous subset.

It is evident from the data that region specific employability has influenced the livelihood and income of the community members. The Central zone with more working days has resulted in better income earnings, whereas the North zone is not significantly generating income to the community members because of fewer working days.

\subsubsection{Poverty Estimation}

The poverty level is estimated based on the official statistics of the Planning Commission of India. The estimation of poverty from the three regions is taken for the analysis based on the Per Capita Income (PCI). The mean value of PCI for Central zone is 1125.72, South zone is 1111.34, and North zone is 998.24 which are evident from the error bar plot (Figure 4).
In addition to the PCI calculation, an attempt is made to evaluate the dynamics of poverty comparing different stages of income i.e., 1 percent change and 5 percent change in PCI. These stages of income are assumed when 1 percent increase or decrease in income and 5 percent increase or decrease in income of the community members to figure out the poverty level of the community members.

Based on the given PCI, it is estimated that out of the three regions the North zone (with 56 percent) comes first in the case of poverty followed by the South zone and the Central zone (Figure 5). The same trend is evident from the stage wise dynamics estimated for the North zone with respect to the poverty whereas South and Central zone is in near to poverty levels.

It is pertinent to understand that, 1 percent increase tends to lower the poverty level of the community and a decrease of 1 percent may lead the community to fall in the circle of poverty. On the other hand, 5 percent increase in their income may help many households to escape from the burden of poverty where 5 percent decrease may gobble up the community into severe poverty.

It can be seen from the analysis (Figure 5 and Table 3 ) that if the income is given up to 5 percent, the rate of poverty will increase from 44.50 percent in the household PCI to 70.80 percent, which indicates 158 


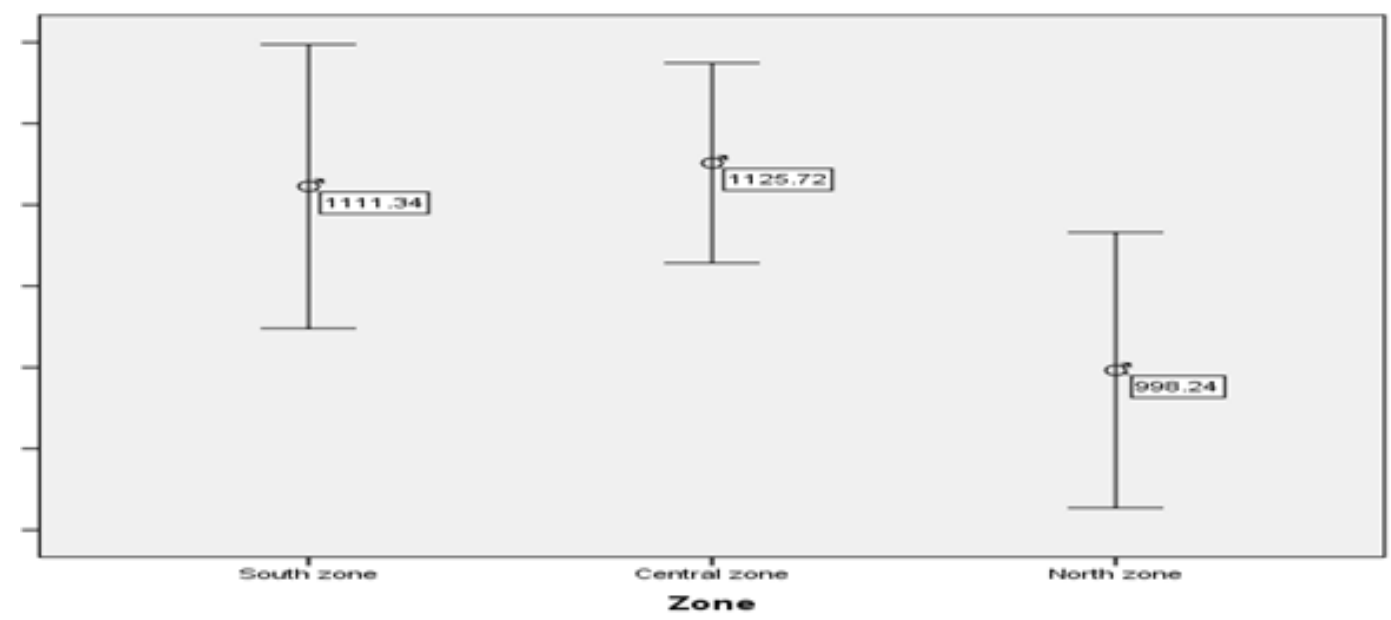

Figure 4. Error bar household PCI.

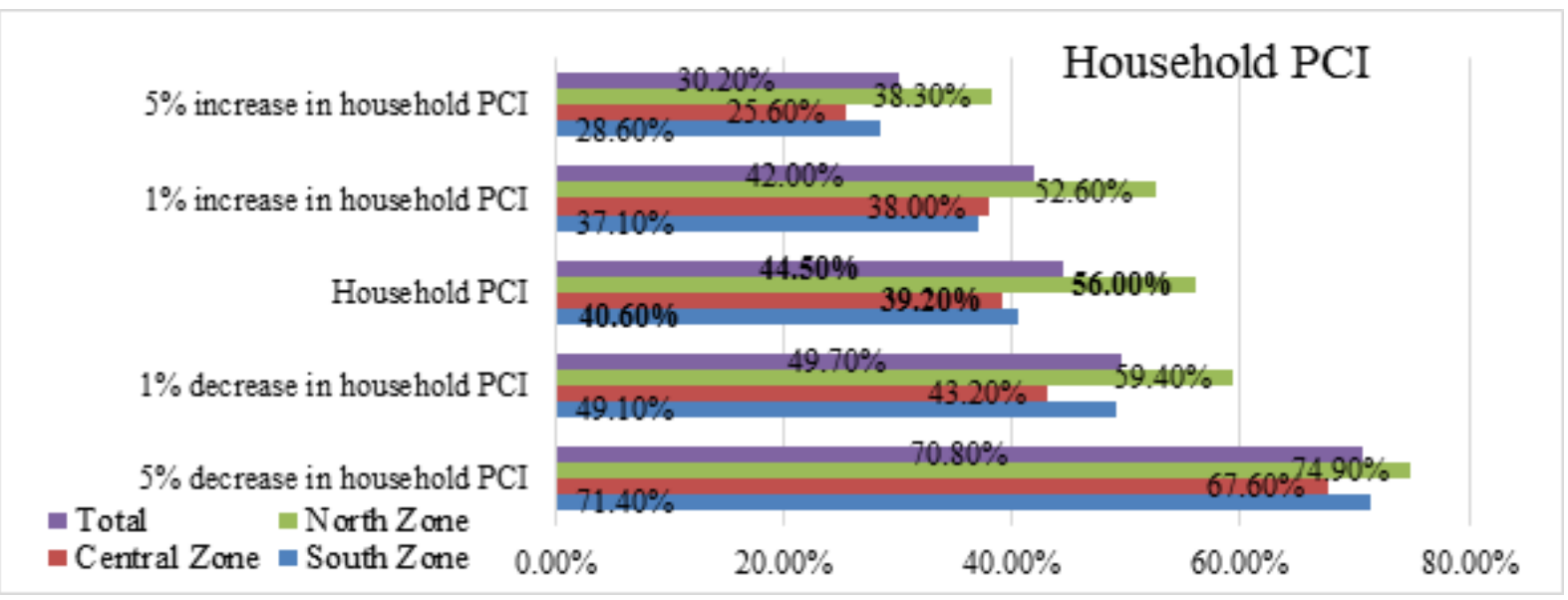

Figure 5. Household poverty in different income stages.

Source: Calculated from the Survey Data

Table 3. Poverty analysis

\begin{tabular}{|c|c|c|c|c|c|c|c|c|c|c|}
\hline \multicolumn{11}{|c|}{ Income poverty } \\
\hline \multirow[t]{2}{*}{ Zone } & \multicolumn{2}{|c|}{$5 \%$ decrease in $\mathrm{PCl}$} & \multicolumn{2}{|c|}{$1 \%$ decrease in $\mathrm{PCl}$} & \multicolumn{2}{|c|}{$\mathrm{HH} \mathrm{PCl}$} & \multicolumn{2}{|c|}{$1 \%$ increase in $\mathrm{PCl}$} & \multicolumn{2}{|c|}{$5 \%$ increase in $\mathrm{PCl}$} \\
\hline & Poor & $\%$ Poor & Poor & $\%$ Poor & Poor & $\%$ Poor & Poor & $\%$ Poor & Poor & $\%$ Poor \\
\hline South Zone & 125 & 71.4 & 86 & 49.1 & 71 & 40.6 & 65 & 37.1 & 50 & 28.6 \\
\hline Central Zone & 169 & 67.6 & 108 & 43.2 & 98 & 39.2 & 95 & 38 & 64 & 25.6 \\
\hline North Zone & 131 & 74.9 & 104 & 59.4 & 98 & 56 & 92 & 52.6 & 67 & 38.3 \\
\hline Total & 425 & 70.8 & 298 & 49.7 & 267 & 44.5 & 252 & 42 & 181 & 30.2 \\
\hline
\end{tabular}

Source: Calculated from the Survey Data

households will be in danger of falling under poverty. On the other hand, if the income level increases by 5 percent the level of poverty reduces from 44.50 percent of household to 30.20 percent. The increasing pattern of income will result in the betterment of their 'income and livelihood' option. It is also noted that the communities in the northern region have high tendency of falling in the circle of poverty, which can 
be well connected with their work participation in that region.

The fall in income will certainly affect the income and livelihood situation of the community members. Hence, it can be established from the income stage-wise analysis that, the early stages of community members before their enrolment in ecotourism can be clubbed to the situation of severe poverty and unemployment. In fact, the community participation in ecotourism however empowered them to attain their subsistence level of income and living.

\subsubsection{Chances of falling in Poverty}

The analysis further explains about the chances of the community members to fall in the circle of poverty. This is calculated from the above Income stage-

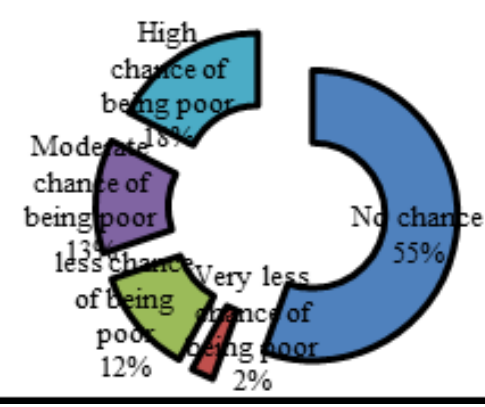

Figure 6. Chances of poverty.

Source: Compiled from the Survey Data wise trials of the poverty analysis. By comparing the trials, it portrays the number of households that may fall into poverty, and the number of households that survive from the burden of poverty. It is heartening to understand (Figure 6) that being employed in the ecotourism programme has benefitted about 55 percent of the households in the non-poor area, whereas 27 percent have moderate or less chance of falling into poverty and the remaining 18 percent of the households have high chance of poverty.

While comparing the zone wise results, the Central zone occupies highest in the no chance of being poor category followed by South Zone. But in the case of North zone it holds the position of high chance of poverty. Hence, establishes that there is significant difference between zones and the community members chances of being poor (Table 4 and Figure 7).

Table 4. Chi-square tests chances of being poor and zone

\begin{tabular}{|l|c|c|c|}
\hline & Value & df & Asymp. Sig. (2-sided) \\
\hline Pearson Chi-Square & $23.128^{\mathrm{a}}$ & 8 & .003 \\
\hline Likelihood Ratio & 23.183 & 8 & .003 \\
\hline Linear-by-Linear Association & 8.564 & 1 & .003 \\
\hline N of Valid Cases & 600 & & \\
\hline
\end{tabular}

a. 2 cells $(13.3 \%)$ have expected count less than 5 . The minimum expected count is 4.38 .

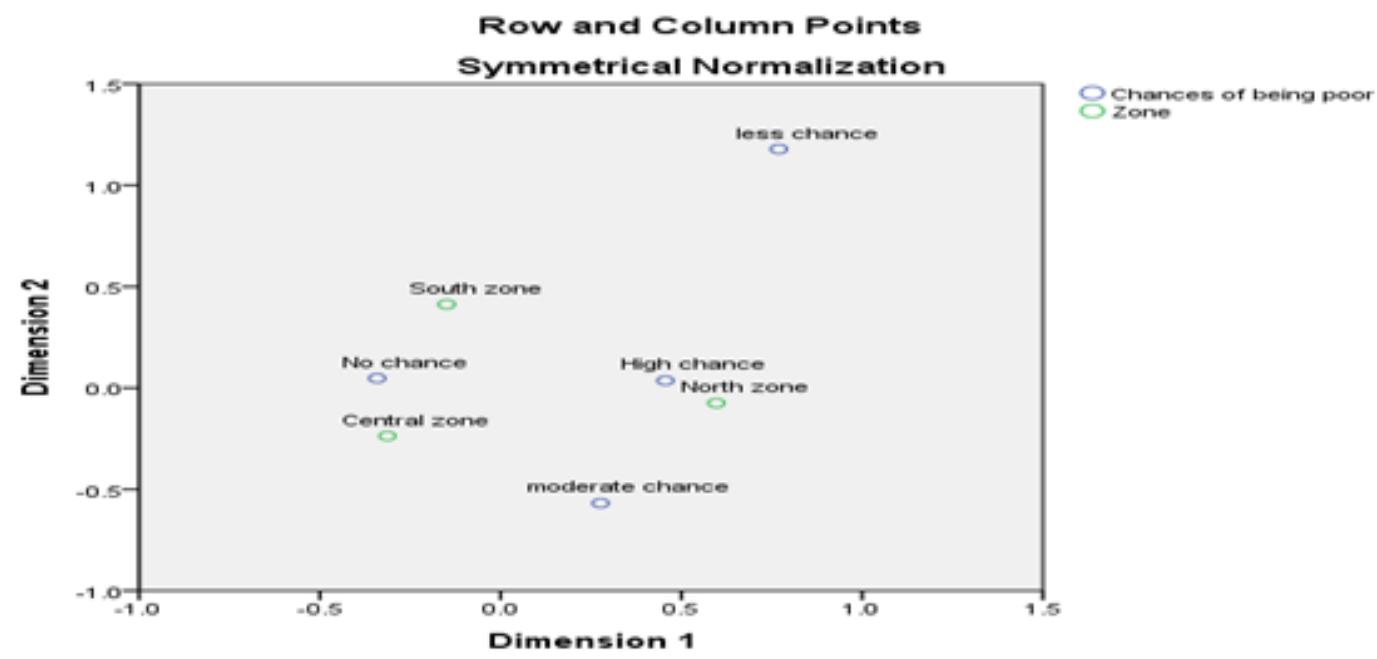

Figure 7. Chances of being poor. 


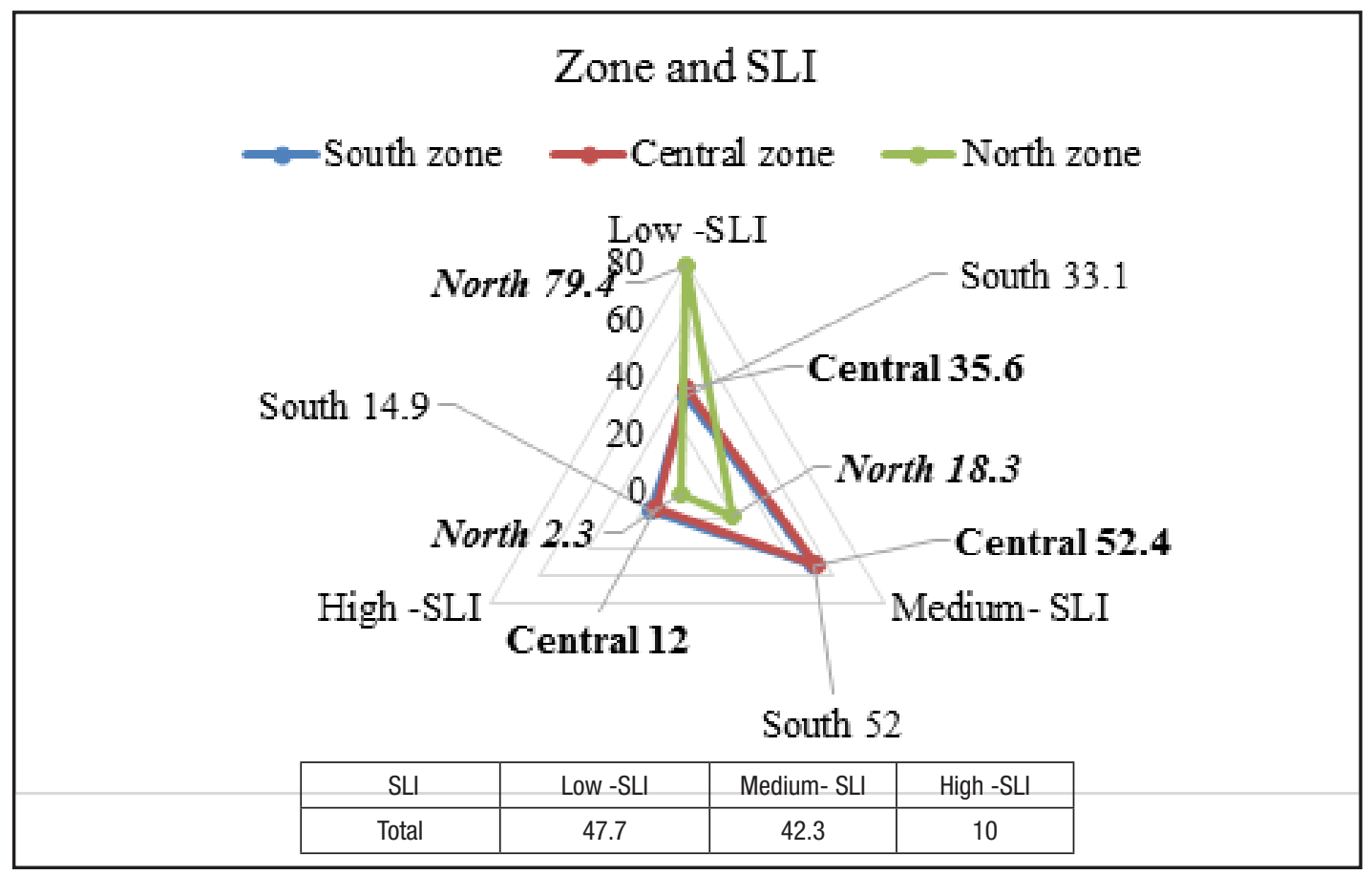

Figure 8. Standard of living and zone.

Source: Calculated from the Survey data

Table 5. SLI and zone - Summary of correspondence

\begin{tabular}{|l|c|c|c|c|c|c|c|c|}
\hline Dimension & $\begin{array}{c}\text { Singular } \\
\text { Value }\end{array}$ & Inertia & \multirow{2}{*}{$\begin{array}{c}\text { Chi } \\
\text { Square }\end{array}$} & & \multirow{2}{*}{ Sig. } & \multicolumn{2}{|c|}{ Proportion of Inertia } & \multicolumn{2}{|c|}{ Confidence Singular Value } \\
\cline { 5 - 8 } & & & & & $\begin{array}{c}\text { Accounted } \\
\text { for }\end{array}$ & Cumulative & $\begin{array}{c}\text { Standard } \\
\text { Deviation }\end{array}$ & Correlation \\
\hline 1 & .410 & .168 & & & .994 & .994 & .035 & .023 \\
\hline 2 & .033 & .001 & & & .006 & 1.000 & .047 & \\
\hline Total & & .170 & 101.714 & $.000^{\mathrm{a}}$ & 1.000 & 1.000 & & \\
\hline
\end{tabular}

a. 4 degrees of freedom

\subsubsection{Well-being of the Community}

The well-being of the community is evaluated based on the Standard of Living Index (SLI). The SLI is framed to understand the well-being and the general living conditions of community members. This framework includes different indicators such as ownership of the house, type of house living, area of house occupied, drinking water facility, sanitation, source of energy/ light, cooking fuel used etc. The indicators were considered from the SLI scores ranging from one to three, where 1 is low SLI score, 2 as medium SLI score and 3 for maximum value i.e, high SLI score.
It can be understood that majority of the community members who are engaged in ecotourism programme have Medium-SLI values (42.3 percent); whereas, 47.7 percent have low SLI and 10 percent have high SLI. The zone-wise analysis (Figure 8 and Table 5) shows that there exists a significant difference in the low, medium, and high SLI values between the three zones.

The (Table 6) shows that two dimensions were derived from the correspondence analysis. The correspondence map in the (Figure 9) highlights the presence of low SLI in north zone and medium SLI lies between the 


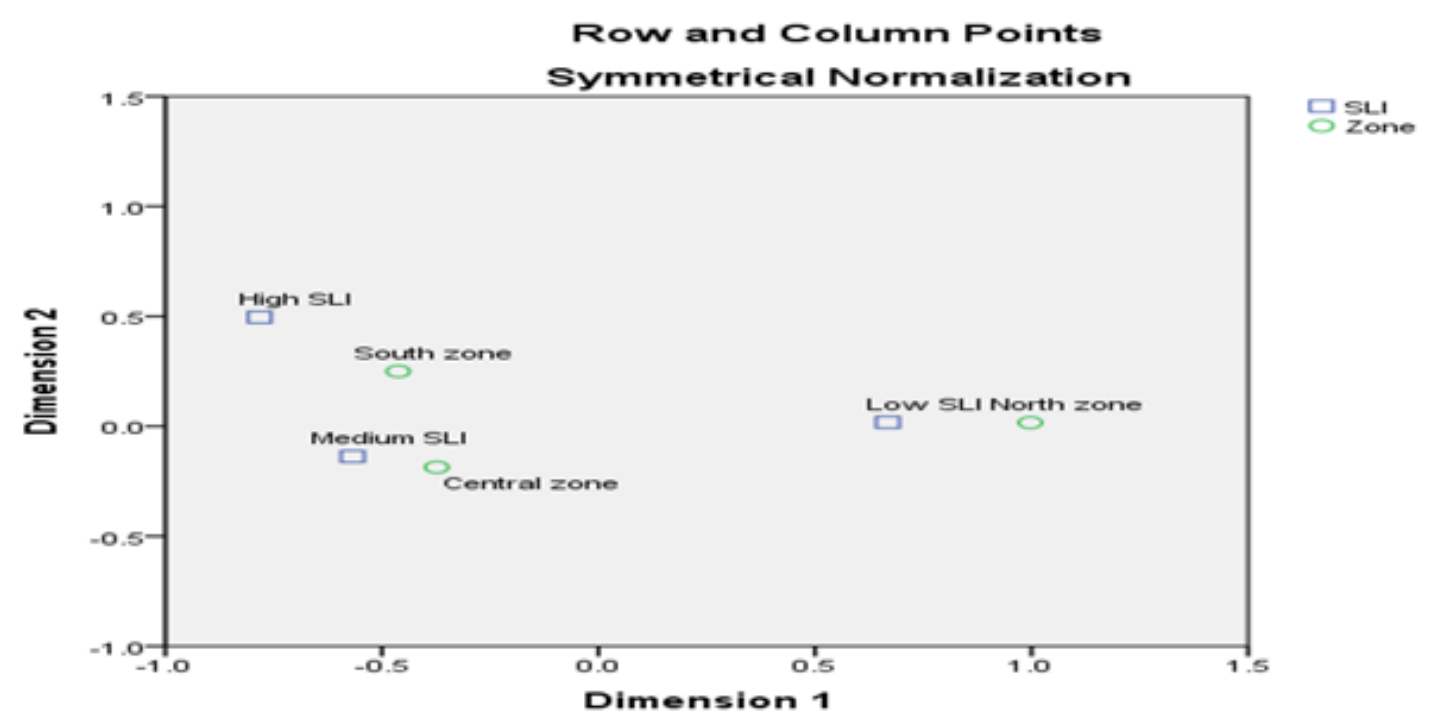

Figure 9. Correspondence map- SLI and zone.

Source: Calculated from Survey data

central zone and south zone; and south zone lies between High SLI and Medium SLI. In short, the community members resided in the south and central zone occupies the medium Standard of living, whereas majority of the community members in the north zone have low Standard of living. Altogether, it is evident that there exist region wise differences with respect to the SLI and this is purely based on the population proportion of the marginalized communities in Kerala.

\subsection{Section 2}

\subsubsection{Community Perception on Sustainable Ecotourism Development}

To understand the perception of the community members on sustainability aspects, a factor analysis with 12 prominent statements were measured to identify the significant factors determining the impact of ecotourism programmes. The scale reliability test with the Cronbach's alpha coefficient shows high reliability of 0.811 for doing the Factor analysis (Table 7). The KMO result 0.868 is greater than the generally accepted 0.60 for a satisfactory factor analysis to proceed (Table 6). It also shows that the Bartlett's test with significant Chi-Square value.

As a result, three factors were identified from the analysis that accounted for 62.4 percent of the total variance (Table 6). Out of this, the first factor explains about 40.76 percent and the second factor with 11.85 percent and the third factor with 9.76 percent of the total variance.

The factors with 0.5 loadings and above are considered for the analysis (Table 7). The first factor with high

Table 6. Total variance explained- impact of ecotourism

\begin{tabular}{|c|c|c|c|c|c|c|}
\hline \multirow[t]{2}{*}{ Component } & \multicolumn{3}{|c|}{ Initial Eigen values } & \multicolumn{3}{|c|}{$\begin{array}{l}\text { Extraction Sums of Squared } \\
\text { Loadings }\end{array}$} \\
\hline & Total & $\begin{array}{l}\% \text { of } \\
\text { Var }\end{array}$ & $\begin{array}{l}\text { Cumu } \\
\%\end{array}$ & Total & $\begin{array}{l}\% \text { of } \\
\text { Var }\end{array}$ & $\begin{array}{l}\text { Cumu } \\
\%\end{array}$ \\
\hline 1 & 4.892 & 40.763 & 40.763 & 4.892 & 40.763 & 40.763 \\
\hline 2 & 1.423 & 11.859 & 52.622 & 1.423 & 11.859 & 52.622 \\
\hline 3 & 1.171 & 9.757 & 62.379 & 1.171 & 9.757 & 62.379 \\
\hline 4 & 0.873 & 7.272 & 69.651 & & & \\
\hline 5 & 0.827 & 6.892 & 76.543 & & & \\
\hline 6 & 0.668 & 5.566 & 82.109 & & & \\
\hline 7 & 0.521 & 4.340 & 86.449 & & & \\
\hline 8 & 0.469 & 3.910 & 90.358 & & & \\
\hline 9 & 0.378 & 3.147 & 93.505 & & & \\
\hline 10 & 0.346 & 2.883 & 96.388 & & & \\
\hline 11 & 0.233 & 1.939 & 98.327 & & & \\
\hline 12 & 0.201 & 1.673 & 100.000 & & & \\
\hline
\end{tabular}

Reliability Statistics: Cronbach's Alpha $=.811, \mathrm{~N}$ of items $=12$; Kaiser-Meyer-Olkin Measure of Sampling Adequacy $=.868$, Approx. Chi-Square $=3054.000$; Bartlett's Test of Sphericity: $\mathrm{df}=66$, Sig. $=0.000$ 
Table 7. Component matrix-impact of ecotourism

\begin{tabular}{|l|c|c|c|}
\hline \multirow{2}{*}{} & \multicolumn{3}{|c|}{ Component } \\
\cline { 2 - 4 } & 1 & 2 & 3 \\
\hline Raise awareness about conservation & 0.861 & 0.091 & -0.167 \\
\hline Creates employment & 0.857 & 0.002 & 0.061 \\
\hline Waste management & 0.836 & -0.050 & 0.221 \\
\hline Increase the income of local peoples & 0.763 & -0.221 & 0.057 \\
\hline Study the probable threat of the area & 0.734 & 0.172 & 0.237 \\
\hline Environmental education and public Awareness & 0.706 & -0.291 & -0.256 \\
\hline Funds for community development & 0.664 & -0.226 & -0.278 \\
\hline Improve quality and standard of living & 0.630 & -0.058 & 0.492 \\
\hline Enable local community participation & 0.108 & 0.788 & -0.092 \\
\hline Ensure natural resource management & 0.218 & 0.541 & 0.233 \\
\hline Build community management organisation & 0.343 & 0.529 & -0.260 \\
\hline Preserving local Cultural & -0.289 & -0.037 & 0.718 \\
\hline
\end{tabular}

loadings constitute about 8 variables that are, 'Raise awareness about conservation', 'Creates employment', 'Waste management', 'Increase the income of local peoples', 'Study the probable threat of the area', 'Environmental Education and public Awareness', 'Funds for community development', and 'Improve quality and standard of living'. Hence, the first factor is "Environment and Economic" highlighting the concern of the community members on sustainability aspect of ecotourism programmes. The second factor is "Local Community Participation in Natural resources management" encompassing the variables like 'Enable local community participation, 'Ensure natural resource management', 'Build community management organization'. It resembles that other than the environment conservation and economic perception of the community about the ecotourism programme, it also enables the empowerment and development of the local peoples of the society to a large extent. The last factor is other than the "preserving local Cultural". The ecotourism provides an option for cultural interaction with the tourists and local residents of the destination provide respect of the both local and foreign culture. This will in turn minimizes negative impacts to the local environment and increases the social well-being of the local communities.

These statements bring the importance of environment protection as a concerning factor for community led ecotourism activities. Also, emphasize on livelihood options and the presence of socio-economic empowerment of the locals. In short, they have opined the richness of sustainable development by joining the ecotourism activities.

\section{Conclusion}

The paper unveils livelihood security of the community members and sustainable ecotourism development of the destination. The result obtained from the study shows a clear-cut picture of community members in terms of the livelihood pattern and how it helped the community members to overcome the burden of poverty vis-a-vis sustainable development of the destination. The local communities have improved immeasurably from the program in terms of livelihood options. However, there exist zone-wise differences with respect to the income and employment, poverty and the well-being of the community members. The central zone poses the good share of benefits drawn from the ecotourism in terms of better income, days of enrolment; low levels of poverty; well-being in terms of better standards and quality of living. The south zone is followed this pattern with a relative less percentages. On the other hand, the north zone picture is dismal in terms of all indicators, hence can be termed as the hub of poverty and low standard of living. The community perception indicates that ecotourism have brought environment and economics benefits, participation of local community and preservation of local culture. The paper suggests for rigorous policy intervention to eliminate the region specific negative effect of community-based ecotourism and recommending destination specific marketing strategies.

\section{References}

Agnes, K. (2004). Is community-based ecotourism a good use of biodiversity conservation funds?. Trends in Ecology and Evolution, 19(5), 232-37. https://doi. org/10.1016/j.tree.2004.03.010. PMid:16701261

Aref, F., \& Gill, S. S. (2009). Rural tourism development through rural cooperatives. Nature and Science, 7(10), 68-73. 
Bijith, G. A., Rajasenan, D. (2016). Socio-economic profile and standard of living aspects of the ecotourism communities of Kerala. South Asian Journal of SocioPolitical Studies, XVI(2).

Fredline, L., Deery, M., \& Jago, L. (2006). Development of a scale to assess the social impacts of tourism within communities. Gold Coast: CRC for Sustainable Tourism.

Kepe, T. (2004). Decentralization when land and resource rights are deeply contested: A case study of the Mkambati eco-tourism project on the wild coast of South Africa. European Journal of Development Research, 25(1), 71 .

Kerala Tourism Statistics (2018). Kerala Tourism Statistics 2017. Department of Tourism, Govt of Kerala.

McCool, S. (1995). Linking tourism, the environment, and concepts of sustainability: Setting the stage. In: Linking Tourism, the Environment, and Concepts of Sustainability, McCool, S., \& Watson, A. (Eds.): Setting the Stage, General Technical Report - Intermountain Research Station, USDA Forest Service 1995 No. INT323 pp. 3-7

NAEB (2008), Ecotourism in Kerala opens scope for Community Involvement in such activities and can work as a big Employment spinner. Available from: http:// www.naeb.nic.in/MTE-Complete_Report.pdf

Neto, F. (2003). A new approach to Sustainable Tourism Development: Moving beyond environmental protection. In Natural Resources Forum (Vol. 27, No. 3, pp. 212-222), Blackwell Publishing Ltd. https://doi.org/10.1111/1477-8947.00056

Rajasenan, D., \& Abraham, B. G. (2012). Livelihood security and socio-economics of Community Based Ecotourism (CBET) in Kerala. South Asian Journal of Socio-Political Studies, XII(2).

Sharpley, R. (2010). The myth of sustainable tourism. Centre of Sustainable Development Working Papers Series 2009, (4).

TCS evaluation report (2002) on Kerala Tourism. Available from: http://tourism.gov.in/CMSPagePicture/file/marketresearch/statewise20yrsplan/Kerala.pdf

Thampi, J. (2005) Ecotourism in Kerala, India: Lessons from the Eco-Development Project in Periyar Tiger Reserve, Nr.13

UNEP, (2013), Green Economy and Trade. Available from: http://www.unep.org/greeneconomy/Portals/88/ GETReport/pdf/Chapitre\%207\%20Tourism.pdf 